\title{
Cold Stress in Captive Great Apes Recorded in I ncremental Lines of Dental Cementum
}

\author{
Alessandra Cipriano \\ Institut für Anthropologie und Humangenetik, München, Deutschland
}

\section{Key Words}

Cold stress $\cdot$ Captive great apes $\cdot$ Incremental lines $\cdot$ Dental cementum

\begin{abstract}
Incremental lines in dental cementum of museum specimens of 11 freeranging great apes were compared to the respective structures in 5 captive specimens of known age-at-death, and with many known life-history parameters. While the dental cementum of the free-ranging apes was regularly structured into alternating dark and light bands, 4 out of 5 captive animals showed marked irregularities in terms of hypomineralized bands which could all be dated to the year 1963. Cementum preservation was insufficient in the fifth specimen and did not permit such a differentiation. All 4 captive apes had been kept in a zoo located in the northern hemisphere, where 1963 was characterized by an extremely cold winter. Since cold stress is a calcium-consuming process, the lack of available calcium in newly forming cementum could be responsible for the observed hypomineralization. The appositional growth characteristics of dental cementum serve as a record for such life-history events.
\end{abstract}

Copyright @ 2002 S. Karger AG, Basel

\section{I ntroduction}

Among the five types of dental cementum, the acellular extrinsic fibre cementum (AEFC) is located exclusively around the cervical third of the root length in all types of permanent teeth, where it fulfills its functional role as an anchor for the tooth in the alveolar cavity [1]. After the tooth's eruption, the AEFC grows in

\footnotetext{
KARGER

Fax +41613061234

E-Mail karger@karger.ch

www.karger.com

(C)2002 S. Karger AG, Basel

0015-5713/02/0731-0021\$18.50/0

Accessible online at:

www.karger.com/journals/fpr
}

\footnotetext{
Dipl.-Biol. Alessandra Cipriano

Robert-Koch-Strasse 3

D-80538 München (Germany)

Tel. +4989 221891, Fax +4989221891

E-Mail A.Cipriano@1rz.uni-muenchen.de
} 
thickness by apposition, which results in annually precipitated incremental lines, easily detectable in histological thin sections. These structures, because they are produced in a circa-annual rhythm, are of great value for estimating age-at-death in mammals [2]. Investigations of primate teeth include the genus Macaca [3-6] and Callithrix [7]. In particular, Kay et al. [5] and Kay and Cant [6] have investigated specimens of known individual age and confirmed the high correlation between the number of incremental lines and age-at-death.

While both growth and genesis of the AEFC are fairly well understood [8, 9], various hypotheses exist as to why incremental lines always appear in pairs of one densely and one less densely mineralized dark and light layer each (cf. fig. 1). In unstained histological sections, hypomineralized light bands correspond to the winter season, while hypermineralized dark bands correspond to the summer season [3]. Since one such dark and light layer together constitute one annual structure, all hypotheses more or less centre around an underlying seasonal rhythm which results in alternating phases of growth and rest in the cementum formation. Current discussion focuses on environmental parameters such as temperature [2], UV radiation and latitude [10] and nutrition [6,11], and physiological parameters such as biomechanical forces $[12,13]$ and endocrinology. However, all parameters listed above are also intertwined; for instance, food availability and endocrinological status vary with season. For the genus Macaca, Kay and Cant [6] were able to show the sensitivity of AEFC precipitation towards the number of dry intervals per year.

In a controlled study on human teeth from a dental care unit, where for each tooth both the actual calendar age of the patient and a variety of life-history parameters assessed by a comprehensive anamnestic and catamnestic query were known, Kagerer and Grupe [14] were able to show that the histological age determination by AEFC analysis in humans is highly correlated with the actual calendar age of the individual as long as the tooth under study was sufficiently supported by the periodontium until extraction, that this correlation holds independent of tooth type, and that diseases like caries, rickets or skeletal traumata do not influence the number of lines. Calcium-consuming processes like pregnancies, skeletal traumata or renal disease, however, had a marked influence on the quality of incremental lines in as much as they resulted in hypomineralized bands precipitated in the respective year.

Since the optical contrast between the light and dark layers of a cementum annulus should be more pronounced in animals from the temperate climates when compared to tropical animals according to Klevezal and Kleinenberg [2], the initial aim of our present study was to compare incremental lines in AEFC in permanent teeth of museum specimens of great apes, to check for possible differences in structure and quality of these lines between free-ranging apes from tropical environments and individuals which had lived in captivity in temperature climates. In the course of this investigation, we were able to detect an apparently stress-related variation in line quality in the captive specimens, which indicates the possibility of tracing important life-history parameters by these appositional structures beyond age-at-death determination in great apes. 
Table 1. Information available for the museum specimens under study, mandibular tooth extracted for histology and respective age of eruption [16]. Comparison of histological age-at-death with known or morphologically assessed age-at-death

\begin{tabular}{|c|c|c|c|c|c|c|}
\hline $\begin{array}{l}\text { Species } \\
\text { (collection number) }\end{array}$ & Origin & Sex & $\begin{array}{l}\text { Morphological/ } \\
\text { known } \\
\text { age-at-death, } \\
\text { years }\end{array}$ & $\begin{array}{l}\text { Mandibular } \\
\text { tooth extracted, } \\
\text { year of eruption }\end{array}$ & $\begin{array}{l}\text { Number of } \\
\text { incremental lines } \\
\text { (mean (M); } \\
\text { SD; CV; range) }\end{array}$ & $\begin{array}{l}\text { Histological } \\
\text { age, years }\end{array}$ \\
\hline \multicolumn{7}{|l|}{ Free-ranging apes } \\
\hline $\begin{array}{l}\text { Gorilla gorilla gorilla } \\
\text { Savage \& Wyman } 1847 \\
(1962 / 333)\end{array}$ & $\begin{array}{l}\text { Rio Muni } \\
\text { Cameroun }\end{array}$ & M & $\begin{array}{l}\text { Young adult } \\
(12-20)\end{array}$ & I2 (5.3-7.0) & $\begin{array}{l}\text { M } 21 ; \text { SD } 0.9 ; \\
\text { CV } 4.3 \% ; \\
\text { range } 10.2-21.9\end{array}$ & $25.4-28.9$ \\
\hline $\begin{array}{l}\text { Gorilla gorilla gorilla } \\
\text { Savage \& Wyman } 1847\end{array}$ & $\begin{array}{l}\text { South-West } \\
\text { Cameroun }\end{array}$ & M & $\begin{array}{l}\text { Old adult } \\
(20-50)\end{array}$ & I1 (4.9-6.6) & $\begin{array}{l}\text { M 21; SD 1.3; } \\
\text { CV } 6.0 \%\end{array}$ & $24.6-28.9$ \\
\hline $\begin{array}{l}\text { Gorilla gorilla gorilla } \\
\text { Savage \& Wyman } 1847 \\
(1911 / 2397)\end{array}$ & $\begin{array}{l}\text { South-West } \\
\text { Cameroun }\end{array}$ & M & $\begin{array}{l}\text { Old adult } \\
(20-50)\end{array}$ & I1 (4.9-6.6) & $\begin{array}{l}\text { M } 29 ; \mathrm{SD} 0.5 ; \\
\text { CV } 1.7 \% ; \\
\text { range } 28.5-29.5\end{array}$ & $33.4-36.1$ \\
\hline $\begin{array}{l}\text { Gorilla gorilla gorilla } \\
\text { Savage \& Wyman } 1847 \\
(1981 / 472)\end{array}$ & $\begin{array}{l}\text { South-West } \\
\text { Cameroun }\end{array}$ & $\mathrm{F}$ & $\begin{array}{l}\text { Young adult } \\
(12-20)\end{array}$ & P4 (5.9-8.4) & $\begin{array}{l}\text { M 21; SD 0.8; } \\
\text { CV 3.8\%; } \\
\text { range } 20.2-21.8\end{array}$ & $26.1-30.2$ \\
\hline $\begin{array}{l}\text { Pongo satyrus borneensis } \\
\text { v. Wurmb } 1784 \\
(1981 / 177)\end{array}$ & $\begin{array}{l}\text { Landak, } \\
\text { Borneo }\end{array}$ & $\mathrm{F}$ & $\begin{array}{l}\text { Young adult } \\
(12-20)\end{array}$ & I1 (6.0-7.0) & $\begin{array}{l}\text { M 8; SD 0.5; } \\
\text { CV 6.2\%; } \\
\text { range } 7.5-8.5\end{array}$ & $13.5-15.5$ \\
\hline $\begin{array}{l}\text { Pongo satyrus borneensis } \\
\text { v. Wurmb } 1784 \\
(1981 / 179)\end{array}$ & $\begin{array}{l}\text { Landak, } \\
\text { Borneo }\end{array}$ & $\mathrm{F}$ & $\begin{array}{l}\text { Young adult } \\
(12-20)\end{array}$ & M1 (ca. 3.5) & $\begin{array}{l}\text { M } 21 ; \text { SD } 2.1 ; \\
\text { CV } 2 \% ; \\
\text { range } 18.9-23.1\end{array}$ & $22.4-26.6$ \\
\hline $\begin{array}{l}\text { Pongo satyrus borneensis } \\
\text { v. Wurmb } 1784 \\
(1981 / 171)\end{array}$ & $\begin{array}{l}\text { Landak, } \\
\text { Borneo }\end{array}$ & M & $\begin{array}{l}\text { Old adult } \\
(20-50)\end{array}$ & I2 (6.0-8.0) & $\begin{array}{l}\text { M 17; SD } 2.1 ; \\
\text { CV } 12.3 \% ; \\
\text { range } 14.9-19.1\end{array}$ & $20.9-27.1$ \\
\hline $\begin{array}{l}\text { Pongo satyrus borneensis } \\
\text { v. Wurmb } 1784 \\
(1981 / 172)\end{array}$ & $\begin{array}{l}\text { Landak, } \\
\text { Borneo }\end{array}$ & M & $\begin{array}{l}\text { Old adult } \\
(20-50)\end{array}$ & P4 (6.0-8.0) & $\begin{array}{l}\text { M 22; SD } 1.3 ; \\
\text { CV } 5.9 \% ; \\
\text { range } 20.7-23.3\end{array}$ & $26.7-31.3$ \\
\hline $\begin{array}{l}\text { Pan troglodytes troglodytes } \\
\text { Gmelin } 1788 \\
(1914 / 741)\end{array}$ & $\begin{array}{l}\text { South-West } \\
\text { Cameroun }\end{array}$ & M & $\begin{array}{l}\text { Old adult } \\
(20-50)\end{array}$ & P4 (6.3-8.3) & $\begin{array}{l}\text { M 26; SD 3.7; } \\
\text { CV } 14.2 \% ; \\
\text { range } 22.3-29.7\end{array}$ & $28.6-38.0$ \\
\hline $\begin{array}{l}\text { Pan troglodytes troglodytes } \\
\text { Gmelin } 1788 \\
(1962 / 330)\end{array}$ & $\begin{array}{l}\text { Rio Muni, } \\
\text { Cameroun }\end{array}$ & $\mathrm{F}$ & $\begin{array}{l}\text { Young adult } \\
(12-20)\end{array}$ & I1 (5.2-6.4) & $\begin{array}{l}\text { M 18; SD } 1.2 ; \\
\text { CV } 6.6 \% ; \\
\text { range } 16.8-19.2\end{array}$ & $22.0-25.6$ \\
\hline $\begin{array}{l}\text { Pan troglodytes troglodytes } \\
\text { Gmelin } 1788 \\
(1913 / 1167)\end{array}$ & & M & $\begin{array}{l}\text { Old adult } \\
(20-50)\end{array}$ & I1 (5.2-6.4) & $\begin{array}{l}\text { M 26; SD 2.2; } \\
\text { CV 8.4\%; } \\
\text { range } 23.8-28.2\end{array}$ & $29.0-34.6$ \\
\hline \multicolumn{7}{|l|}{ Captive apes } \\
\hline $\begin{array}{l}\text { Gorilla gorilla gorilla } \\
(1965 / 293 ; \text { Raja) }\end{array}$ & $\begin{array}{l}\text { Chicago } \\
\text { (16 years), } \\
\text { Hannover, } \\
\text { Germany } \\
\text { (14 days), } \\
\text { Amsterdam }\end{array}$ & $\mathrm{F}$ & $\begin{array}{l}17 \text { years, } \\
\text { birth } 1948, \\
\text { death } 1965\end{array}$ & I1 (4.9-6.6) & $\begin{array}{l}\text { Minimum } 9 \\
\text { (cf. text) }\end{array}$ & $13.9-15.6$ \\
\hline $\begin{array}{l}\text { Pongo pygmaeus } \\
\text { (1966/203; Andy) }\end{array}$ & $\begin{array}{l}\text { Bronx } \\
\text { (18 years), } \\
\text { Hannover, } \\
\text { Germany }\end{array}$ & M & $\begin{array}{l}\text { ca. } 21 \text { years } \\
\text { birth bef. } 1947 \text {, } \\
\text { death1966 }\end{array}$ & I1 (6.0-7.0) & $\begin{array}{l}\text { M 15; SD } 0.8, \\
\text { CV 5.3\%; } \\
\text { range } 14.2-15.8\end{array}$ & $20.2-22.8$ \\
\hline $\begin{array}{l}\text { Pongo pygmaeus } \\
\text { (1971/576; 'Maxi') }\end{array}$ & $\begin{array}{l}\text { München, } \\
\text { Germany }\end{array}$ & M & $\begin{array}{l}18 \text { years, } \\
\text { birth } 1954, \\
\text { death } 1971\end{array}$ & I1 (6.0-7.0) & $\begin{array}{l}\text { M 12; SD 0.7; } \\
\text { CV 5.8\%; } \\
\text { range } 11.3-12.7\end{array}$ & $17.3-19.7$ \\
\hline $\begin{array}{l}\text { Pan troglodytes } \\
(1966 / 110)\end{array}$ & $\begin{array}{l}\text { Hannover, } \\
\text { Germany }\end{array}$ & $\mathrm{F}$ & $\begin{array}{l}\text { min. } 14 \text { years, } \\
\text { death } 1966\end{array}$ & $\mathrm{I} 2(5.0-7.3)$ & $\begin{array}{l}\text { M 8; SD } 1.3 ; \\
\text { CV } 1.6 \% ; \\
\text { range } 6.7-9.3\end{array}$ & $11.7-16.6$ \\
\hline $\begin{array}{l}\text { Pan troglodytes } \\
(1965 / 262)\end{array}$ & $\begin{array}{l}\text { Hannover, } \\
\text { Germany }\end{array}$ & M & $\begin{array}{l}\text { ca. } 18 \text { years, } \\
\text { death } 1965\end{array}$ & I1 (5.2-6.4) & $\begin{array}{l}\text { M 12; SD 1.9, } \\
\text { CV } 15.8 \% ; \\
\text { range } 10.1-13.9\end{array}$ & $15.3-20.3$ \\
\hline
\end{tabular}

$\mathrm{SD}=$ Standard deviation; $\mathrm{CV}=$ coefficient of variation of incremental line counts. 


\section{Material}

The skeletons of the great apes under study are housed in the primatology section of the Anthropological Department of the Anthropological and Palaeoanatomical Collection in Munich, Germany [catalogue available through internet www.lrz-muenchen.de/ NatSamm/ Anthropologie/Anthro.html]. The mandibles of 16 individuals (chimpanzees, gorillas and orangutans; cf. table 1) were first morphologically inspected, only teeth without carious lesions or pathological periodontal affections were forwarded to histology. Since the collection material is very valuable, only one tooth per mandible was carefully extracted, and the crown separated from the root with a diamond saw. The crown was later fixed to a cast of the root and the tooth replaced in the mandible.

Out of the 16 individuals, 11 had been shot in their natural environment around the turn of the 20th century and forwarded to natural history museums or collections. The geographical origin, year of 'collection' and morphological sex and age-at-death diagnoses were available for these animals. For the 5 captive apes, information was available about their sex, geographical origin, transfer to a zoological garden, diet and life circumstances in captivity. Since all 5 animals were subadults, with their deciduous dentition when they were transferred to a zoo, at least an approximate calendar age-at-death ('known age-at-death') could be assessed by adding the years spent in captivity until death to the dental age in the year of their arrival. Considerable data concerning their living conditions in captivity were available due to the kind cooperation of the zoological gardens involved. Table 1 summarizes the individual data from each specimen available to us for histological inspection.

\section{Methods}

Extracted roots were embedded into Biodur E12 resin (Gunter v. Hagen, Heidelberg: 100 parts Biodur E12 mixed with 28 parts hardener E1) and sectioned with a rotating diamond saw microtome (Leica 1600). Since no prior investigation on incremental lines of the teeth of great apes was available, longitudinal sections of $70 \mu \mathrm{m}$ thickness were first prepared for each tooth. These longitudinal sections confirmed the expected location of AEFC and, in addition, the suitability of AEFC for further analysis independent from tooth type.

After this initial study, for the subsequent age of death determination, cross sections in the region of the AEFC were taken. Cross sections are more suitable for age of death determination than longitudinal sections because they can show the complete structure of the dental cementum. It is, therefore, possible to study an incremental line around the whole root. In this way, the absence, for example, of an incremental line formation due to a onesided paradontosis of the tooth can be observed and therefore a bias in the age determination can be avoided.

A minimum of 4 cross-sections of $70 \mu \mathrm{m}$ thickness was prepared from the AEFC of every specimen. Thin sections were cleaned ultrasonically for $10 \mathrm{~min}$ in $70 \%$ ethanol and subsequently dehydrated in 80 and $96 \%$ ethanol and then twice in absolute ethanol and xylol. Fixed onto glass trays, unstained thin sections were inspected by light microscopy (Nikon AFX-DX) with slightly decentred phase contrast as recommended by Grosskopf [15], and several photographs were taken from each section. Incremental lines (one line = one dark/light layer pair) on each photograph were counted at least 5 times under inclusion of the dentin/cementum junction (eruption line [cf. 14]) and the outermost layer as one additional layer each. Age-at-death was determined by addition of the age of tooth eruption (table 1 [data from 16]) to the average number of incremental lines. All ageing was done 'blindly', that is the morphological or known age-at-death of the specimen under study was not known to the investigator.

This more subjective method for the age-of-death estimation was preferred to a standardized computer-based method. An earlier study on the digital image analysis of dental cement sections [17] has shown that the analysis of digital images by light/dark profiles can lead to enormous faults in the age-of-death estimation [Cipriano, unpubl. data]. The differ- 


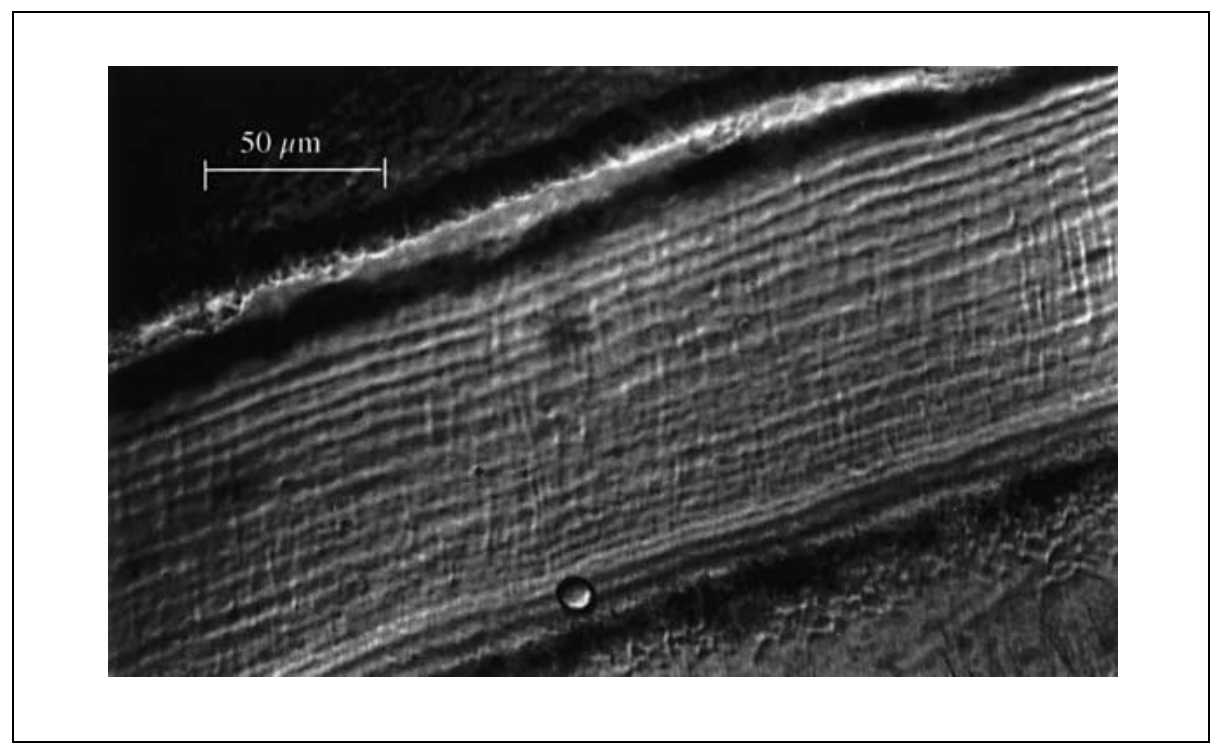

Fig. 1. Thin section through the AEFC of a free-ranging great ape (gorilla 1962/333). Regularly deposited dark and light bands.

ence in the intensity of the grey values throughout a cross section makes it impossible for the computer to recognize all different incremental lines.

\section{Results}

Most of the histological specimens revealed excellent to very satisfying morphological features of the cementum. In the case of a few specimens only, the incremental lines appeared more fuzzy, most probably due to the use of $\mathrm{H}_{2} \mathrm{O}_{2}$ in the course of maceration and preparation of the skeletons (fig. 5). One individual only, a captive chimpanzee ('pan 1966/100', table 1), had such a badly preserved cementum that the layers were very hard to separate from each other. For 4 out of the 5 captive individuals, histological age-at-death excellently matched their known ageat-death. The cementum of gorilla 'Raja' was, unfortunately, less well preserved (fig. 5), thus only a minimum number of lines could be differentiated. However, the histological age differed from the known calendar age by 1.4-3.1 years only (table 1) and is therefore within the precision range of this ageing method for humans [14, 15]. Out of the 11 free-ranging individuals, 4 specimens appeared to be histologically older than estimated morphologically. All these specimens had been morphologically assessed as young adults, but would have been in their 20 s by AEFC counts (table 1). While the AEFC of all 11 free-ranging animals showed clearly identifiable incremental lines with a succession of regular light and dark bands of very even thickness (fig. 1), all captive individuals showed marked irregularities in terms of mineralization and band width (fig. 2-5). 


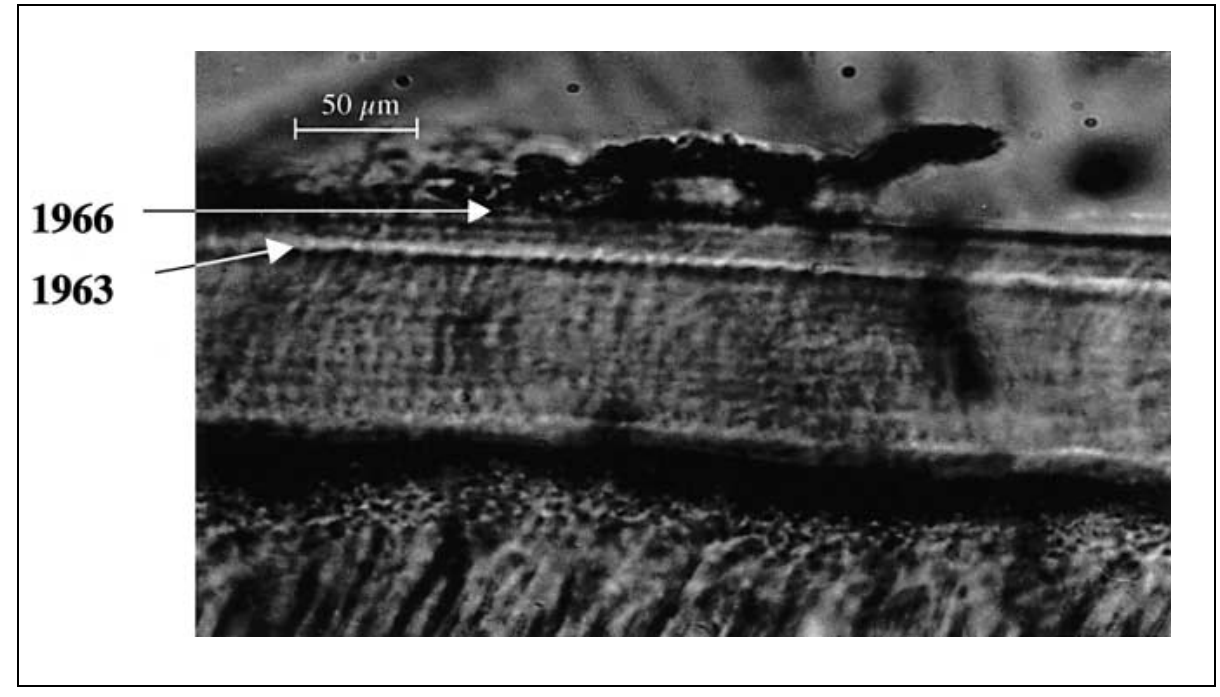

Fig. 2. Thin section through the AEFC of orangutan 'Andy', showing a broad and hypomineralized band which was deposited in the winter of 1963. $1966=$ Year of death.

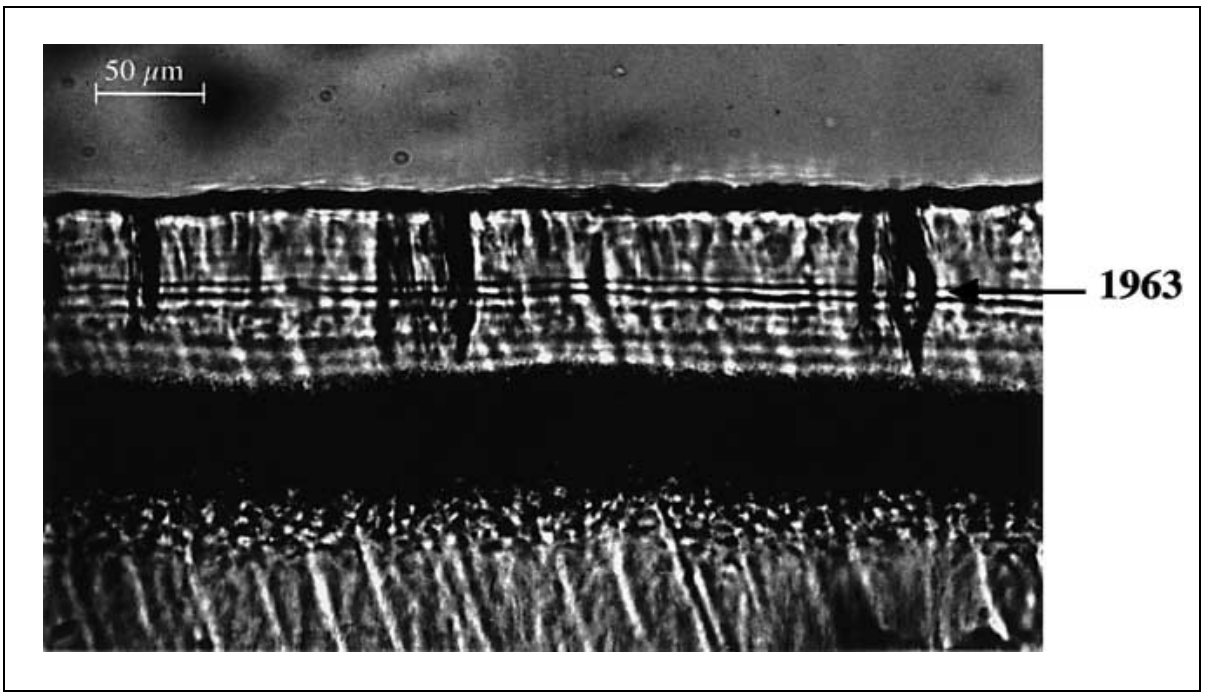

Fig. 3. Thin section through the AEFC of orangutan 'Maxi'. Hypomineralized layer dated 1963. 


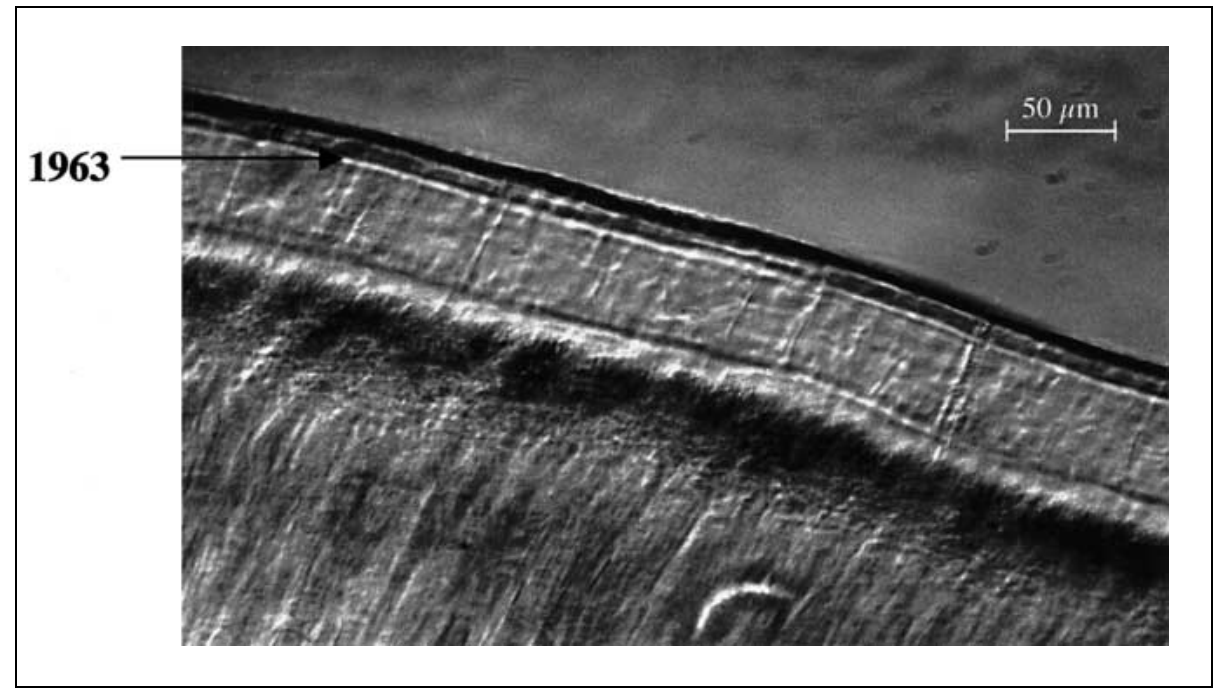

Fig. 4. Thin section through the AEFC of pan 1965/252. Hypomineralized layer deposited in 1963.

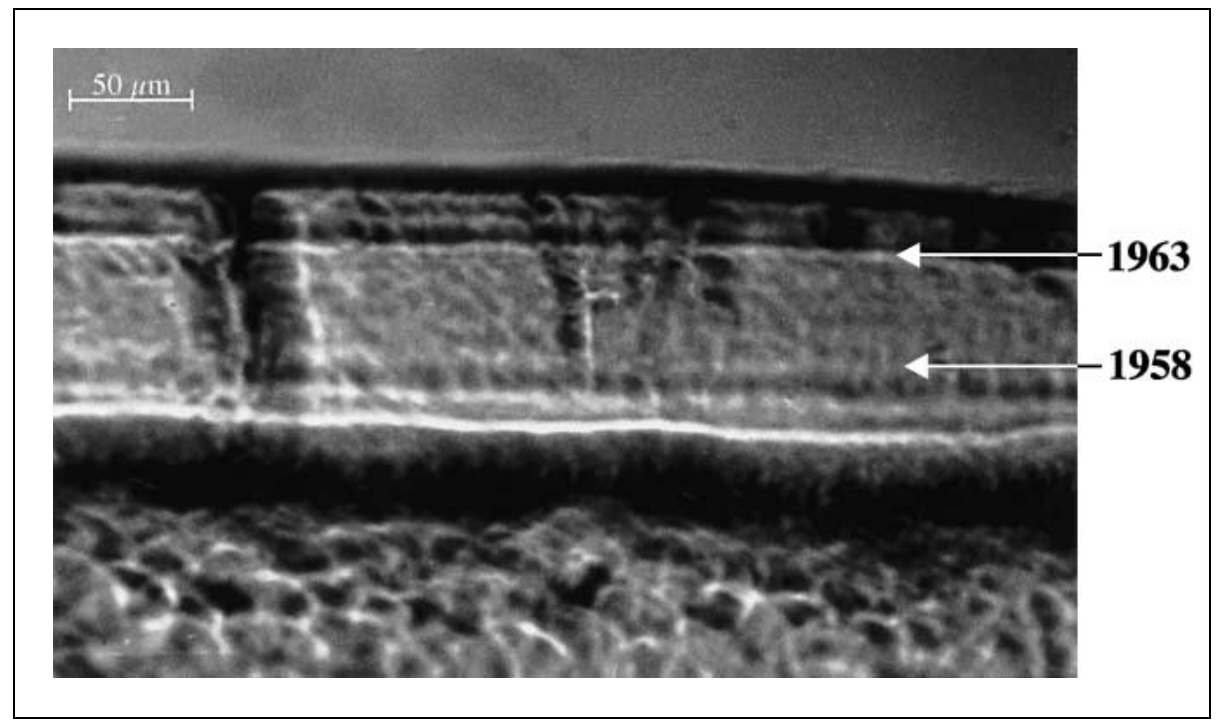

Fig. 5. Thin section through the AEFC of gorilla 'Raja'. The fuzzy appearance of the layers is most probably a maceration artifact. As a result, only a minimum number of annuli could be assessed (cf. table 1). Despite the fuzzy appearance of the bands, two clearly hypomineralized layers are datable to the years 1963 and 1958. 
Taking the agreement of the histological age with the known age-at-death in these animals together with the records of the zoological gardens which documented both year and season of death of the apes, it was possible to determine the year of formation of these conspicuous bands. For instance, the orangutan 'Andy' had died on May 25 in the year 1966, thus the very broad and apparently hypomineralized band was precipitated in 1963 (fig. 2). The marked translucent bands in the cementum of the orangutan 'Maxi', the chimpanzee 'pan 1965/262' and the gorilla 'Raja' were all also dated to the year 1963; with 'Raja' exhibiting a second such line, which was most probably formed in 1958 (fig. 3-5). Due to the bad preservation of the cementum in 'pan 1966/110', no discrimination in terms of line quality was possible. Since all animals had been transferred to a zoo with their deciduous dentition, all incremental lines analyzed had been produced in captivity. It is a striking phenomenon that in all 4 captive animals with better preserved AEFC, a disruption of the precipitation of even bands took place in the winter of 1963.

\section{Discussion}

While the age-at-death estimates by AEFC counts were in good accordance to the known ages-at-death for the captive animals, the discrepancies obtained for the free-ranging individuals deserve some explanation. 'Young adults' were morphologically aged as younger than their histological ageing, however, morphological age-at-death assessment of individuals with a full permanent dentition and all epiphyses fused permitted the determination of a biological age within a rather broad range only.

In the past, dental eruption schedules have mainly derived from studies on captive animals. It is well known that captive animals erupt their teeth earlier than wild ones, up to 19 months for single teeth [18]. The use of dental eruption schedules derived from captive animals to age wild animals can therefore lead to differences in the morphological and histological age of the investigated wild animals. The body size of the animals is also important for the characterization of an individual as 'young adult', 'adult' or 'old adult'. In every study on the growth and development of mammals, an individual is called adult when it has reached its maximum height. Estimates of body height and body mass often exist for animals in laboratories, zoos or natural habitats [19]. It is known that animals kept in captive or provisioned habitats tend to increase in body mass. The age of free-ranging animals, based on such studies, will therefore be underestimated due to their lower body mass.

Also, the still not fully understood 'doubling phenomenon', well known from human AEFC, may have obscured the histological data. Such doublings (i.e. the precipitation of two light and two dark band layers per yearly incremental line) are found in a low percentage of human teeth and occur either throughout the whole dentition or within single teeth only [14]. Also, great ape AEFC precipitation may be sensitive to the number of dry intervals per year, in analogy to the findings of Kay and Cant [6] for the genus Macaca.

We will focus further on the differences in line quality between free-ranging and captive specimens. Since none of the cementum layers of the free-ranging individuals showed any irregularities in the incremental lines, uneven layers present in the captive individuals may be due to specific living conditions in the zoo. All of 
the individuals inspected by us spent their lives in captivity between the 1940s and 1970s, when living conditions for apes in zoos were far from optimal. Food shortages apparently did not occur, in contrast the animals tended to be fed too much and be gaining weight [20]. This holds especially for the orangutan 'Andy', the diet of which was recorded in detail by Crandall [21]. Aged 9 years, 'Andy' weighed $101 \mathrm{~kg}$ and lived on a mixed diet with a 'milk mixture', which was fed twice a day. In 1959, 'Andy' was undoubtedly overweight at $203 \mathrm{~kg}$ and his food was consequently reduced, especially in terms of the calcium-rich 'milk mixture' until he reached $180 \mathrm{~kg}$ in the year 1962 [21]. Since 'Andy' produced the hypomineralized incremental line in the following winter, malnutrition is evidently not responsible for this phenomenon.

Besides nutrition, climatic parameters should have an influence on the formation of incremental lines (see Introduction). All captive animals described in this paper had lived in cages with access to an open air area (Bronx Zoo [21, 22]; Chicago Zoo [A. Henderson, K. Lukas, pers. commun.]; Hannover Zoo [K. Brunsing, pers. commun.]; München Zoo [H. Wiesner, pers. commun.], however, no information was available as to how frequently and regularly the animals had access to the open air area during the cold season. It is however very probable that during a very cold winter, the inside temperatures would also have been lower than normal. Two gorillas in London Zoo died in the course of the very cold winter of 1962/63 [23], and 2 orangutans died in Dresden during the severe winter of 1940, when the temperatures even in the indoor cages dropped to only $+8{ }^{\circ} \mathrm{C}$ [24]. These reports strongly suggest that very cold temperatures induce, at least, considerable stress in these tropical animals. It is noteworthy that all 4 captive apes investigated had produced a marked hypomineralized incremental line in the course of the extremely cold winter of 1963, characterized by very low average temperatures both in the United States and on the continent [data for Germany, see 25; data for New York available through internet www.ncdc.noaa.gov/ol/climate/climatedata.html]. Earlier in 1958, a comparably severe winter had occurred in the eastern parts of the United States only. During the cold winter of 1958, the gorilla 'Raja' (Bronx Zoo) produced a hypomineralized layer, while the orangutan 'Andy' (Chicago Zoo), still living on a calcium-rich diet, did not.

Cold stress has an impact on the serum calcium level, which could be responsible for a lack of available calcium for the mineralization of newly forming tissue. Since AEFC is not remodeled, low calcium incorporation will result in a lasting hypomineralized layer. The first response to low temperatures is shivering, which is a calcium-consuming process because of the key role calcium plays in the actomyosin system during muscular activity. Even more important is the hormonal response, with the production of elevated levels of thyroid hormones (T3/T4) and catecholamines [26]. While thyroid hormones activate both the $\mathrm{Na}^{+}-$and $\mathrm{K}^{+}$ATPases in the membranes of liver, muscle and kidney cells, and thus stimulate the so-called 'non-shivering thermogenesis', catecholamins induce an overall catabolism and are set free by exocytosis as a response to stress situations, and also during muscular activity. Since the interaction of catecholamines with the $\alpha$ - and $\beta$ receptors of their target cells lead to elevated cytoplasmatic calcium concentrations with their cell-specific consequences, gross metabolism in a warm-blooded animal is much more calcium-consuming in the cold season than in the summer season [26]. Considerable cold stress could, therefore, well lead to a lack of available cal- 
cium for AEFC precipitation and could explain the striking coincidence between extreme winters and hypomineralized incremental lines.

Not only are these 'stress layers' less mineralized than the regular winter bands, they also seem to be broader. However, this result is hard to support statistically, and optical artefacts cannot be totally excluded. Nevertheless, both amount and diameter of the Sharpey's fibres are a function of mastication forces in as much as more and thicker fibres are produced under higher physical loads [27]. Since it was usual to feed the apes more, and also more frequently, in the cold season to meet their energetic demands, the increased breadth of the bands may be either due to elevated biomechanical forces or due to an enhanced matrix production that mineralized poorly.

For humans, Kagerer and Grupe [14] were able to show that several calciumconsuming processes (pregnancies, skeletal trauma, renal disease) led to the precipitation of a hypomineralized light layer in the incremental annulus of the respective year, however these did not influence the number of incremental lines. Therefore, all these parameters may also have been responsible for the conspicuous translucent lines observed in the captive apes. No such parameters however are reported for the animals under study, and even if one allows for certain gaps in the documentation for the 4 animals, it would be highly unlikely that one or the other of these circumstances occurred in all the apes in the same year. The coincidence of hypomineralized lines and climatic stress is obvious.

Since the free-ranging individuals investigated by us exhibit a clear differentiation between dark and light layers of the incremental lines (fig. 1), we could not confirm the less pronounced contrast between these bands in the cementum annuli in tropical animals as reported by Klevezal and Kleinenberg [2]. However, our findings do not contradict any of the hypotheses mentioned above concerning this structural differentiation of the AEFC. Tropical climates do not completely lack any seasonality: the number of sunshine hours and, therefore, the UV radiation dose, and also the average temperature differs in the dry and wet season. Also, feeding strategies of great apes differ in a seasonal way [e.g. 28]. All these parameters will have an impact on the calcium availability at the spot of cementogenesis and may be responsible for the differential mineral densities in the cementum microstructures.

\section{Acknowledgments}

We are most indebted to Drs. A. Henderson and K. Lukas (Chicago), K. Brunsing (Hannover) and Prof. Dr. H. Wiesner (München) for their kind help and important information on the living conditions of the captive apes under study.

\section{References}

1 Plagman HC: Lehrbuch der Parodontologie. München, Hanser, 1998.

2 Klevezal GA, Kleinenberg SE: Age determination of mammals from annual layers in teeth and bones. Academy of Sciences, USSR, 1967; translated by Israel Progr Scient Transl, Jerusalem 1969.

3 Wada K, Ohtaishi N, Hachiya N: Determination of age in the Japanese monkey from growth layers in the dental cementum. Primates 1978;19:775-784. 
4 Yoneda M: Growth layers in dental cementum of saguinous monkeys in South America. Primates 1982;23:460-464.

5 Kay RF, Rasmussen DT, Beard KC: Cementum annulus counts provide a means for age determination in Macaca mulatta (Primates, Anthropoidea). Folia Primatol 1984;42:85-95.

6 Kay RF, Cant JGH: Age assessment using cementum annulus counts and tooth wear in a freeranging population of Macaca mulatta. Am J Primatol 1988;15:1-15.

7 Stott GG, Raymond FS, Barnet ML: Cemental annulation as an age criterion in the common marmoset (Callithrix jacchus). J Med Primatol 1980;9:274-285.

8 Sequeira P, Bosshardt DD, Schroeder HE: Growth of acellular extrinsic fiber in human premolars of adolescents. J Periodont Res 1992;27:134-142.

9 Schroeder HE: Biological problems of regenerative cementogenesis: Synthesis and attachment of collagenous matrices on growing and established root surfaces. Int Rev Cytol 1992;142:1-59.

10 Pike-Tay A: Red deer hunting in the Upper Paleolithic of south-west France: A study in seasonality. BAR Int Ser Oxford, 1991, p 569.

11 Lieberman DE: The biological basis for seasonal increments in dental cementum and their application to archaeological research. J Archaeol Sci 1994;21:525-539.

12 Williamson G, Payne WJA: Animal Husbrandry in the Tropics. London, Longman, 1978.

13 Lieberman DE: Life history variables preserved in dental cementum microstructure. Science 1993;261:1162-1164.

14 Kagerer P, Grupe G: Age-at-death diagnosis and determination of life-history parameters by incremental lines in human dental cementum as an identification aid. Forensic Sci Int 2001;2939: $1-10$.

15 Grosskopf B: Individualaltersbestimmung mit Hilfe von Zuwachsringen im Zement bodengelagerter Zähne. Z Rechtsmed 1990;103:351-359.

16 Smith BH, Crummettt TL, Brandt KL: Ages of eruption of primate teeth: A compendium for aging individuals and comparing life histories. Yearb Phys Anthrop 1994;37:177-231.

17 Geusa G, Bondioli L, Capucci E, Cipriano A, Grupe G, Savorè C, Macchiarelli R: Dental cementum annulations and age at death estimates; in Bondioli L, Macchiarelli R (eds): Digital Archives of Paleobiology. 2. Milano, E-Lisa Sas, 1999.

18 Phillips-Conroy JE, Jolly CJ: Dental eruption schedules of wild and captive baboons. Am J Primatol 1988;15:17-29.

19 Smith RJ, Jungers WL: Body mass in comparative primatology. J Hum Evol 1997;32:523-559.

20 Erwin J, Deni R: Strangers in a strange land: Abnormal behaviour or abnormal environments; in Erwin J, Maple TL, Mitchell G (eds): Captivity and Behaviour. New York, VNR, 1979, pp 1-20.

21 Crandall LS: Management of Wild Animals in Captivity. Chicago, Chicago University Press, 1964.

22 Edwards M: New York Zoological Park and Aquarium; in Zuckerman L (ed): Great Zoos of the World. Their Origins and Significance. Boulder/Colorado, Westview, 1980, pp 125-134.

23 Groves CP: Gorillas. Herrsching, Pawlak, 1970.

24 Gensch W: 125 Jahre Primatenhaltung im Zoologischen Garten Dresden; in Hohmann HD (ed): Haltung und Zucht von Primaten. Jena, Fischer, 1958.

25 Schönwiese CD: Klima im Wandel. Stuttgart, DVA, 1992.

26 Siegenthaler W (ed): Klinische Pathophysiologie, ed 7. Stuttgart, Thieme, 1994.

27 Akiyoshi M, Inoue M: On the functional structure of the cementum. Bull Tokyo Med Dent Univ 1963;10:41-59.

28 Sommer V, Amman K: Die grossen Menschenaffen. München, BLV, 1998. 